Original Article

\title{
COMPARISON OF THE EFFICACY (IN TERMS OF STONE EXPULSION) OF TAMSULOSIN VERSUS NIFEDIPINE IN DISTAL URETERIC STONE
}

\author{
Mudassar Saeed Pansota ${ }^{a}$, Sharmeen Shafqat ${ }^{\mathrm{b}}$, Shafqat Ali Tabassum ${ }^{\mathrm{C}}$ Mumtaz Rasool ${ }^{\mathrm{d}}$, \\ Muhammad Shahzad Saleem ${ }^{e}$ \\ ${ }^{a}$ Assistant Professor, Urology, Shahida Islam Medical College, Lodhran.

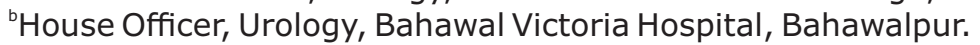 \\ 'Professor and Head Department of Urology, Bahawal Victoria Hospital, Bahawalpur. \\ ${ }^{\mathrm{d} A s s o c i a t e}$ Professor, Urology, Bahawal Victoria Hospital, Bahawalpur. \\ ${ }^{\mathrm{e} A s s i s t a n t}$ Professor, Urology, Bahawal Victoria Hospital, Bahawalpur.
}

\begin{abstract}
:
INTRODUCTION: In western prosperous countries, a great research has been done on these two medicines in urolithiasis. Extent of disease is varying from developing countries to developed countries, specially due to late identification of diseases, late in examination which enhances the consequences of disease in ureteral stone or in any other disease.
\end{abstract}

OBJECTIVES: To compare the efficacy (in terms of stone expulsion) of tamsulosin versus nifedipine in victims with distal ureteral stone.

MATERIAL AND METHOD: All of 86 patients with distal ureteric stone, 20 to 50 years of both genders were included. Patients with proximal ureteric stricture, gross hydronephrosis, previous ureteral surgery and solitary kidney were excluded. After informed, written consent, all selected cases were divided in two groups by lottery method. In group A patients, tamsulosin was given while in group B patients, nifedipine was given. All patients were followed weekly by the researcher till 4 weeks and ultrasonography in both groups was done by the one consultant radiologist for evaluation of efficacy.

RESULTS: Mean age was $32.29 \pm 6.81$ years. Out of these 86 patients, $53(61.63 \%)$ were male and $33(38.37 \%)$ were females with. Mean size of stone was $6.69 \pm 1.49 \mathrm{~mm}$. Stone expulsion was seen in $37(86.05 \%)$ patients in group A (tamsulosin group) and $25(58.14 \%)$ patients in group B (nifedipine group) with $\mathrm{p}$-value of 0.004 .

CONCLUSION: This survey concluded that efficacy (in terms of stone expulsion) of tamsulosin is better as compared to nifedipine in distal ureteric stone

KEYWORDS: Distal Ureter Stone, Tamsulosin, Nifedipine, Expulsion.

\section{INTRODUCTION:}

The third most frequent disease of urinary tract in whole world is urolithiasis, which effect usually two-percent population with almost fifty percent recurring rate ${ }^{[1]}$. Ureteric stone occupies a main place in routine medical practices and experts are demanded to recommend appropriate treatments ${ }^{[2]}$. Recently, by using the therapies of pharmacology, use of perceptive wait approaches have been expanded ${ }^{[3]}$. Medical expulsive therapy [MET] is suggested to elevate stone crossing and decrease the requirement of extracorporeal shock wave lithotripsy ${ }^{[4]}$. Most of the patients with urolithiasis contain stones of small size that are present in distal ureter and able to cross continuously. Removal of stone and time to move the stones depends upon size of stone and it's location ${ }^{[5]}$.

Two categories of therapy are present, alpha adrenergic receptor antagonist and calcium. Recently, for distal ureteral calculi, good consequences have been shown by MET, related to stone removal and lessen the ureteral colic

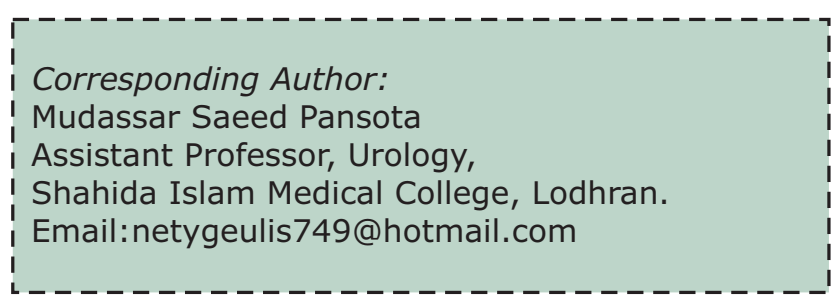


pain, by the use of nifedipine and prednisolone and can regulate the functioning of ureter, blocked by stones. Alpha receptor blocker is using in this interest is tamsulosin ${ }^{[6,7]}$. Gandhi HR et $\mathrm{al}^{[8]}$ has shown remarkable differences in stone removal rate by using tamsulosin $(80 \%)$ compared to nifedipine (55\%) for distal ureteric stone. In most of 28-day trials ${ }^{[10]}$ containing stones of greater than $15 \mathrm{~mm}$, the rate of distal ureteric stone crossing was $34-71 \%$ in control group, $76.1-81 \%$ in group treated with nifedipine and $78.3-100 \%$ in group treated with tamsulosin.

In western prosperous countries, a great research has been done on these two medicines in urolithiasis. Extent of disease is varying from developing countries to developed countries, specially due to late identification of diseases, late in examination which enhances the consequences of disease in ureteral stone or in any other disease. So randomized controlled trial to compare the efficiency (in terms of stone expulsion) of tamsulosin versus nifedipine in distal ureteric stone in local population.

\section{MATERIALS AND METHODS:}

This randomized controlled trial was performed at the outpatient Department of Urology, Bahawal Victoria Hospital, Bahawalpur, and Shahida Islam Teaching Hospital, Lodhran from $1^{\text {st }}$ April 2018 to $31^{\text {st }}$ March 2019. A sample of 86 patients was recommended through consecutive non probability sampling technique. Inclusion criteria was patients of age 20-50 years of distal ureteric stone (presence of an acoustic shadow $\leq 10 \mathrm{~mm}$ in intramural part of ureter on ultrasonography and radio-opaque shadow in the juxtavesical part below the pelvic brim) of size $\leq 10 \mathrm{~mm}$. Patients with gross hydronephrosis, pregnant women, h/o previous ureteral surgery, solitary kidney and ureterocele were excluded. After taking permission from Institutional Ethical Review Committee, the consent of the patients was sought.
Selected patients were allowed to choose a slip from all confounded slips [half with letter $A$, half with letter $B$ ] and the patient was allowed in that respective category. In category $A$ patients, $0.4 \mathrm{mg}$ Tamsulosin was given daily at bed time for 4 weeks while in category B patients, $30 \mathrm{mg}$ nifedipine was given daily for 4 weeks. Both categories were given Tab. Ciprofloxacin $500 \mathrm{mg}$ 12 hourly and tab diclofenac Sodium 50mg. Compliance in both groups was noted by subjective assessment. All patients were followed weekly by the researcher till 4 weeks and ultrasonography in both categories was done by the one consultant radiologist for evaluation of efficacy (in terms of stone expulsion from ureter).

All the data was entered and inspected by the use of SPSS version 20.0. The numeric variables were represented as mean deviation and variance. Consistency and proportions were calculated for numeric variables. Chi square was used to contrast the efficacy and $p$-value $\leq$ 0.05 was regarded as significant.

\section{RESULT:}

The mean age of patients in category $A$ was $32.19 \pm 7.15$ years and in category $B$ was 32.40 \pm 6.54 years. Majority of the patients 58 $(67.44 \%)$ were between $20-35$ years of age and expressed in table I.

Out of these 86 patients, $53(61.63 \%)$ were male and 33 (38.37\%) were females. Mean size of stone was $6.69 \pm 1.49 \mathrm{~mm}$. Mean size of stone in category A was $6.81 \pm 1.33 \mathrm{~mm}$ and in category B was $6.75 \pm 1.56 \mathrm{~mm}$ as shown in Table II. Mean BMI was $28.77 \pm 5.62 \mathrm{~kg} / \mathrm{m}^{2}$. Stone expulsion was seen in 37 (86.05\%) patients in category A (tamsulosin group) and $25(58.14 \%)$ patients in category B (nifedipine group) with $\mathrm{p}$-value of 0.004 as shown in Table III. 
Table-I: Age distribution for both categories $(n=86)$.

\begin{tabular}{|c|c|c|c|c|c|c|}
\hline \multirow[b]{2}{*}{ Age (years) } & \multicolumn{2}{|c|}{$\begin{array}{c}\text { category A } \\
(n=43)\end{array}$} & \multicolumn{2}{|c|}{ Category $B(n=43)$} & \multicolumn{2}{|c|}{ Total $(n=86)$} \\
\hline & $\begin{array}{l}\text { No. of } \\
\text { patients }\end{array}$ & \%age & No. of patients & \%age & No. of patients & \%age \\
\hline $20-35$ & 30 & 69.77 & 28 & 65.12 & 58 & 67.44 \\
\hline $36-50$ & 13 & 30.23 & 15 & 34.88 & 28 & 32.56 \\
\hline Mean \pm SD & \multicolumn{2}{|c|}{$32.19 \pm 7.15$} & \multicolumn{2}{|c|}{$32.40 \pm 6.54$} & \multicolumn{2}{|c|}{$32.29 \pm 6.81$} \\
\hline
\end{tabular}

Table-II: Distribution of patients according to stone size.

\begin{tabular}{|c|c|c|c|c|c|c|}
\hline \multirow[b]{2}{*}{ Stone size } & \multicolumn{2}{|c|}{ category A $(n=43)$} & \multicolumn{2}{|c|}{ category B $(n=43)$} & \multicolumn{2}{|c|}{ Total $(n=86)$} \\
\hline & Frequency & \%age & Frequency & $\%$ age & Frequency & \%age \\
\hline 1-5 mm & 11 & 25.58 & 10 & 23.26 & 21 & 24.42 \\
\hline $6-10 \mathrm{~mm}$ & 32 & 74.42 & 33 & 76.74 & 65 & 75.58 \\
\hline Mean \pm SD & \multicolumn{2}{|c|}{$6.81 \pm 1.33$} & \multicolumn{2}{|c|}{$6.75 \pm 1.56$} & \multicolumn{2}{|c|}{$6.69 \pm 1.49$} \\
\hline
\end{tabular}

Table-III: Comparison of Efficiency (in terms of stone removal) between both categories $(n=86)$.

\begin{tabular}{|c|c|c|c|c|c|c|c|}
\hline & & \multicolumn{2}{|c|}{$\begin{array}{c}\text { category A } \\
(n=43)\end{array}$} & \multicolumn{2}{|c|}{ category B $(n=43)$} & \multirow{2}{*}{$\begin{array}{c}\text { Chi } \\
\text { square } \\
\text { values }\end{array}$} & \multirow{2}{*}{ p-value } \\
\hline & & Frequency & \%age & Frequency & \%age & & \\
\hline \multirow[b]{2}{*}{ EFFICACY } & Yes & 37 & 76.67 & 25 & 40.0 & \multirow[b]{2}{*}{8.32} & \multirow[b]{2}{*}{0.004} \\
\hline & No & 06 & 23.33 & 18 & 60.0 & & \\
\hline
\end{tabular}

\section{DISCUSSION:}

Intercessional treatment includes medical expulsive therapy (MET), extracorporeal shock wave lithotripsy (ESWL), percutaneous nephrolithotomy, ureteroscopy, laparoscopic techniques. With the help of researches, it became confirmed that potential of medical treatments to aid stone removal has elevated ${ }^{[10-}$ ${ }^{13]}$. Related studies have modernized our comprehension of capacity of MET in aiding stone removal. Also, MET decreases the hospital costs stops unimportant operations integrated risks and problems. In recent practices, MET either with nifedipine or tamsulosin has revealed too increase stones passing chances of normal size LUS $^{[13]}$. although, European urological associations revealed that these two drugs are affordable therapy option to help ureteral stone removal ${ }^{[14,15]}$. This study was conducted for the comparison of the efficiency (in terms of stone removal) of tamsulosin versus nifedipine in patients with distal ureteric stone.

It was expressed by meta-analysis that tamsulosin can enhance the stone removal rate comparative to nifedipine in victims with LUS. Subgroup analysis expressed no remarkable distinction in the two medicines regarding to high or low side effects ${ }^{[16]}$. Micali et al $^{[17]}$ described that in patient having higher-mid ureteral stones, nifedipine drug was effective and acceptable than that of tamsulosin for stone removal. Picozzi et al ${ }^{[1]}$ issued systematic review and meta-analysis of medical expulsive technology for LUS and suggested that there are no differences between tamsulosin and nifedipine categories regarding to stone removal rate.

In particular Morita $T$ et $\mathrm{al}^{[19]}$ elaborated effective result in acceleration of lower tract ureteral stone passing by use of alpha-1 blocker. Cao D et $\mathrm{al}^{[16]}$, In a randomly controlled study, suggested a remarkable differences in 
removal rate of stone between the groups dosed with tamsulosin and controlled category. Same result were shown by Dellabella et $a^{[20]}$. Trial by Vincendeau et $\mathrm{al}^{[22]}(\mathrm{n}=130)$ and Hermanns et $a^{[21]} \quad(n=100)$ comprises mean stone size of $3-4 \mathrm{~mm}$, stone removal rate of $76 \%$ and $85 \%$, respectively, with tamsulosin contrasted with $70 \%$ and $88 \%$, respectively, with placebo, that had no importance. Trail by Ferre et al ${ }^{[23]}$. Confirmed advantage was assessed with stone removalin $76 \%$ of the tamsulosin category contrasted with $64 \%$ in the accurate care category $(P=.50)$.

In a meta-analysis ${ }^{[25]}$, There was no differences between active therapy and placebo $(p=0.77)$, or between tamsulosin and nifedipine $(p=0 \cdot 76)^{[14]}$.

On the whole, it is concluded that efficacy (in terms of stone expulsion) of tamsulosin is better as compared to nifedipine in distal ureteric stone.

\section{CONCLUSION:}

This study concluded that efficacy (in terms of stone expulsion) of tamsulosin is better as compared to nifedipine in distal ureteric stone. So, we recommend that tamsulosin should be used routinely in our general practice to avoid invasive procedures in such patients.

\section{CONFLICT OF INTEREST:}

There is no declared conflict of interest.

\section{ETHICAL REVIEW COMMITTEE:}

Ethical review committee of the said institute has reviewed and approved this article.

\section{REFERENCES:}

1. Picozzi SCM. Management of ureteral calculi and medical expulsive therapy in emergency departments. J Emerg Trauma Shock.2011;4:70-6.

2. Basnet $S$, Shrestha PM, Shakya R. Prospective study on the efficacy of tamsulosin in medical management of distal ureteric stones. J Chitwan Med Coll. 2013;3(3):56-61.
3. Wood KD, Gorbachinsky I, Gutierrez J. Medical expulsive therapy. Indian J Urol. 2014;30:60-4.

4. Ahmad $\mathrm{H}$, Azim $\mathrm{W}$, Akmal M, Murtaza B, Mahmood A,Nadim A, et al. Medical expulsive treatment of distal ureteral stoneusing tamsulosin. J Ayub Med Coll Abbottabad. 2015;27(1):48-50.

5. Ye ZQ, Yang $\mathrm{H}$. Medical expulsion therapy for urinary calculi. Chin Med J (Engl). 2012;125:3765-768.

6. Fan B.Can tamsulosin facilitate expulsion of ureteral stones: a meta-analysis of randomized controlled trials. Int J Urol. 2013;20:818-30.

7. Ye ZQ.A multicentre, prospective, randomized trial: comparative efficacy of tamsulosin and nifedipine in medical expulsive therapy for distal ureteric stones with renal colic. BJU Int. 2011;108: 276-79.

8. Gandhi HR, Agrawal C. The efficacy of tamsulosin vs. nifedipine for the medical expulsive therapy of distal ureteric stones: a randomised clinical trial. Arab J Urol. 2013;11:405-10.

9. Osorio L, Lima E, Autorino R, Marcelo F. Emergency management of ureteral stones: recent advances. Int J Urol. 2008;24:461-6.

10. Hollingsworth JM. Medical therapy to facilitate urinary stone passage: a meta analysis. Lancet 2006;368:1171-1179.

11. Fan B. Can tamsulosin facilitate expulsion of ureteral stones? A meta-analysis of randomized controlled trials. Int J Urol 2013;20:818-830.

12. Gravas S. The use of tamsulosin as adjunctive treatment after ESWL in patients with distal ureteral stone: Do we really need it? Results from a randomized study. Urol Res 2007;35:231-235.

13. Singh A, Alter HJ, Littlepage A. A systematic review of medical therapy to facilitate passage of ureteral calculi. Ann Emerg Med 2007;50:552-563.

14. Preminger GM. Guideline for the management of ureteral calculi. J Urol 2007; 178:2418-2434.

15. Wood KD, Gorbachinsky I, Gutierrez J. Medical expulsive therapy. Indian J Urol 
2014;30:60-64.

16. Cao D, Yang $Y$, Liu L, Yuan $H$, Qian S, Lv X, et al. A comparison of nifedipine and tamsulosin as medical expulsive therapy for the management of lower ureteral stones without ESWL. Sci Rep. 2014; 4: 5254.

17. Micali S. Efficacy of expulsive therapy using nifedipine or tamsulosin, both associated with ketoprofene, after shock wave lithotripsy of ureteral stones. Urol Res 2007;35:133-137.

18. Sayed MA, Yosr AM, Abdalla MA, El-azab A. Efficacy of tamsulosin in medical expulsive therapy for distal ureteral calculi. Scand J Urol Nephrol 2008;42:59-62.

19. Morita T, Wada I, Suzuki T, Tsuchida S. Characterization of alpha-adrenoreceptor subtypes involved in regulation of ureteral fluid transport. Tohoku J Exp Med 1987;152:111-8.

20. Dellabella M, Milanese G, Muzzonigro G. Efficacy of tamsulosin in the medical management of juxtavesical ureteral stones. J Urol 2003;170:2202-5.

21. Hermanns T, Sauermann P, Rufibach K, et al. Is there a role for tamsulosin in the treatment of distal ureteral stones of $7 \mathrm{~mm}$ or less? results of a randomised, doubleblind, placebo-controlled trial. Eur Urol. 2009; 56:407-412.

22. Vincendeau $S$, Bellissant $E$, Houlgatte A. Tamsulosin hydrochloride vs placebo for management of distal ureteral stones: a multicentric, randomized, double-blind trial. JAMA Intern Med. 2010;170:20212027.
23. Ferre RM, Wasielewski JN, Strout TD, et al. Tamsulosin for ureteral stones in the emergency department: a randomized, controlled trial. Ann Emerg Med. 2009;54:432-439; 439.e431-432.

24. Pickard R, Starr K, MacLennan G, Lam T, Thomas R, Burr J, et al. Medical expulsive therapy in adults with ureteric colic: a multicentre, randomised, placebocontrolled trial. Lancet 2015; 386: 341-49.

25. Wang $H$, Man LB, Huang GL, Li GZ, Wang JW. Comparative efficacy of tamsulosin versus nifedipine for distal ureteral calculi: a meta-analysis. Dovepress. 2016;2016:1257-65.

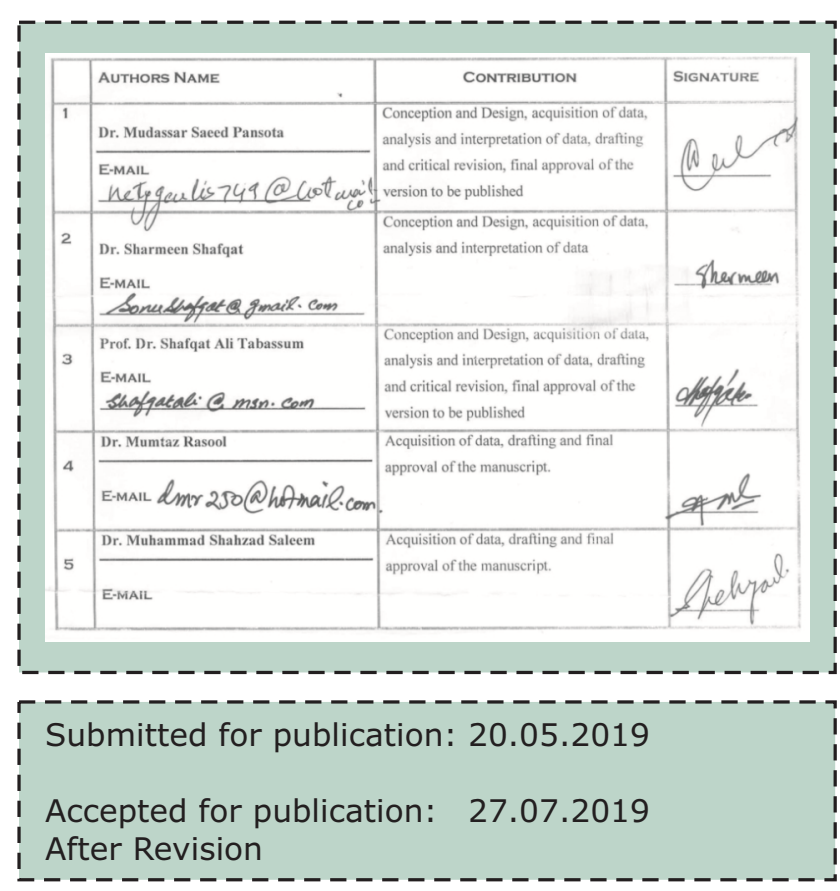

Failures are often the results of timidity and fears; disappointments are the results of bashfulness; hours of leisure pass away like summer-clouds, therefore, do not waste opportunity of doing good Hazrat Ali (Karmulha Wajhay) 